\title{
Development of an indirect competitive enzyme- linked immunosorbent assay applied to the Botrytis cinerea quantification in tissues of postharvest fruits
}

Martín A Fernández-Baldo, Jorge G Fernández, Sirley V Pereira, Germán A Messina, Eloy Salinas, Julio Raba and María I Sanz Ferramola*

\begin{abstract}
Background: Botrytis cinerea is a phytopathogenic fungus responsible for the disease known as gray mold, which causes substantial losses of fruits at postharvest. This fungus is present often as latent infection and an apparently healthy fruit can deteriorate suddenly due to the development of this infection. For this reason, rapid and sensitive methods are necessary for its detection and quantification. This article describes the development of an indirect competitive enzyme-linked immunosorbent assay (ELISA) for quantification of B. cinerea in apple (Red Delicious), table grape (pink Moscatel), and pear (William's) tissues.

Results: The method was based in the competition for the binding site of monoclonal antibodies between $B$. cinerea antigens present in fruit tissues and $B$. cinerea purified antigens immobilized by a crosslinking agent onto the surface of the microtiter plates. The method was validated considering parameters such as selectivity, linearity, precision, accuracy and sensibility. The calculated detection limit was $0.97 \mu \mathrm{g} \mathrm{mL}-1$ B. cinerea antigens. The immobilized antigen was perfectly stable for at least 4 months assuring the reproducibility of the assay. The fungus was detected and quantified in any of the fruits tested when the rot was not visible yet. Results were compared with a DNA quantification method and these studies showed good correlation.
\end{abstract}

Conclusions: The developed method allowed detects the presence of B. cinerea in asymptomatic fruits and provides the advantages of low cost, easy operation, and short analysis time determination for its possible application in the phytosanitary programs of the fruit industry worldwide.

\section{Background}

Botrytis cinerea is a pathogen ascomycete, which causes gray mold on a large number of economically important agricultural and horticultural crops [1-4]. This ubiquitous fungal pathogen is present often as latent infection. Latency is generally defined as the period between infection and the appearance of visible symptoms and can in the case of $B$. cinerea be long and variable [5-8]. Consequently, an apparently healthy fruit can deteriorate suddenly due to the development of this latent infection $[9,10]$.

\footnotetext{
* Correspondence: msanz@unsl.edu.ar

INQUISAL, Departamento de Química. Universidad Nacional de San Luis, CONICET. Chacabuco 917. D5700BWS. San Luis, Argentina
}

Many synthetic fungicides are used as the principal mean of controlling this important postharvest disease [11]. However, the growing public concern over the health and environmental hazards associated with fungicide use in orchards, the development of fungicide resistant strains of B. cinerea [12], and the deregistration of some of the most effective fungicides [13], have generated a great interest in the development of alternative methods to control the postharvest disease caused by this fungal pathogen.

To prevent the indiscriminate use of fungicides, a sensitive and reliable method to early determination of the fungus in fruit tissues becomes crucial. The ability to detect latent infections in fruit tissues should prove useful not only for early disease management but also for

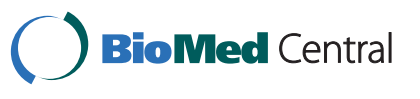


identifying infected fruit in postharvest. In addition, the quantification of the pathogen is necessary for the application of alternative methods of control, such as biological control using antagonist microorganisms because the success of this method depend of the ratio antagonist/ pathogen [14].

The detection of fungus in fruit includes classical methods such as isolation on selective media, which is useful but subject to limitations [15] due to many pathogens can be masked by overgrowth of faster growing fungi. Other methods, such as quantitative real-time polymerase chain reaction (Q-PCR), or reverse transcription polymerase chain reaction (RT-PCR) represent new tools for the detection of the pathogens by determination of their DNA/RNA [16-25]. Unfortunately these methods are expensive and not easy to perform routinely, because they require highly qualified personnel and need sophisticated instrumentation [26,27]. In addition, to methods mentioned previously, some direct enzymelinked immunosorbent assays (ELISAs) using microtiter plates have been developed for the detection of $B$. cinerea in pear steam, grape juice, and plants [28-32], but at present has not been reported any validated method based in an indirect competitive immunoassay for detection and quantification of the mentioned fungus in tissues of fruits.

The aim of this study was the development and corroboration of a sensitive and specific ELISA for $B$. cinerea quantification in fruit post-harvest tissues such as apple (Red Delicious), table grape (pink Moscatel), and pear (William's). The determination of B. cinerea was based in an indirect competitive immunoassay that used purified B. cinerea antigens, which were immobilized on the surface of the microtiter plates by a crosslinking agent. The B. cinerea specific monoclonal antibodies (BC-12. CA4) were allowed to react immunologically with immobilized antigens and with $B$. cinerea antigens present in the fruit sample. These antigens compete for the binding site of antibodies. Those antibodies whose binding site reacted with the immobilized antigens were detected by a horseradish peroxidase (HRP) enzymelabeled second antibodies specific to mouse IgG, using a substrate solution. The response colour obtained from the product of enzymatic reaction $(\mathrm{P})$ was measured by an ELISA microplate reader at $490 \mathrm{~nm}$ and the colour signal was inversely proportional to the amount of $B$. cinerea antigens present in the fruit sample. The method was validated considering parameters such as selectivity, linearity, precision, accuracy, and sensibility. The results obtained were correlated with the damage produced in the infected fruits by the pathogen and with the DNA of $B$. cinerea that was recovered from the lesions.

\section{Results and discussion}

\section{Preparation of antigens and samples}

The preparation of purified antigen and samples included a treatment with liquid nitrogen with the aim of exposing the antigenic sites. In preliminary tests this step was not taken into account, and the resulting signal was very low. According Meyer et al, the monoclonal antibody, BC-12.CA4 recognizes an antigen, possibly a glycoprotein, with the antigenic binding site on L-rhamnose and the treatment with liquid nitrogen help to expose these sites in high quantities [29].

Purified antigens were immobilized on the surface of the microtiter plates by a crosslinking agent and were stable for at least 4 months.

\section{Quantitative test for the determination of B. cinerea}

The fruit samples consisted in apples (Red Delicious), table grape (pink Moscatel), and pear (William's) without any postharvest treatment and were purchased from a local fruit market in San Luis City, Argentina

The method was applied for the determination of $B$. cinerea in 50 commercial fruit samples. All fruits were selected as much as possible homogeneous in maturity and size.

Because the developed method was based in a competition between $B$. cinerea purified antigens immobilized onto the surface of the microtiter plates, and $B$. cinerea antigens present in fruit tissues, the absorbance at 490 $\mathrm{nm}$ was inversely proportional to the amount of the $B$. cinerea antigen present in the fruit sample.

A standard curve for the immunoassay procedure was carried out following our protocol with a series of purified antigens that covered a relevant range of concentration (0-100 $\mu \mathrm{g} \mathrm{mL}^{-1}$ antigen) (Figure 1). The linear regression equation was $\mathrm{A}=1.18-0.01 * \mathrm{C}_{B}$. cinerea, with the linear regression coefficient $\mathrm{r}=0.998$ and $\mathrm{a}$ detection limit (DL) of $0.97 \mu \mathrm{g} \mathrm{mL} \mathrm{L}^{-1}$. The DL was considered to be the concentration that gives a signal three times the standard deviation (SD) of the blank.

The coefficient of variation (CV) for the determination of $25 \mu \mathrm{g} \mathrm{mL}^{-1}$ B. cinerea was below $4 \%$ (six replicates).

The precision of the ELISA assay was checked with control solutions of 5,25 and $75 \mu \mathrm{g} \mathrm{mL}^{-1}$ B. cinerea purified antigens concentrations. The within-assay precision was tested with 5 measurements in the same run for each sample. These series of analyses were repeated for three consecutive days in order to estimate the between-assay precision. The results obtained are presented in Table 1 . The $B$. cinerea immunoassay showed good precision; the $\mathrm{CV}$ within-assay values were below $4 \%$ and the between-assay values were below $7 \%$.

The correlations between the lesion diameters of the fruit samples and the amount of $B$. cinerea antigen 


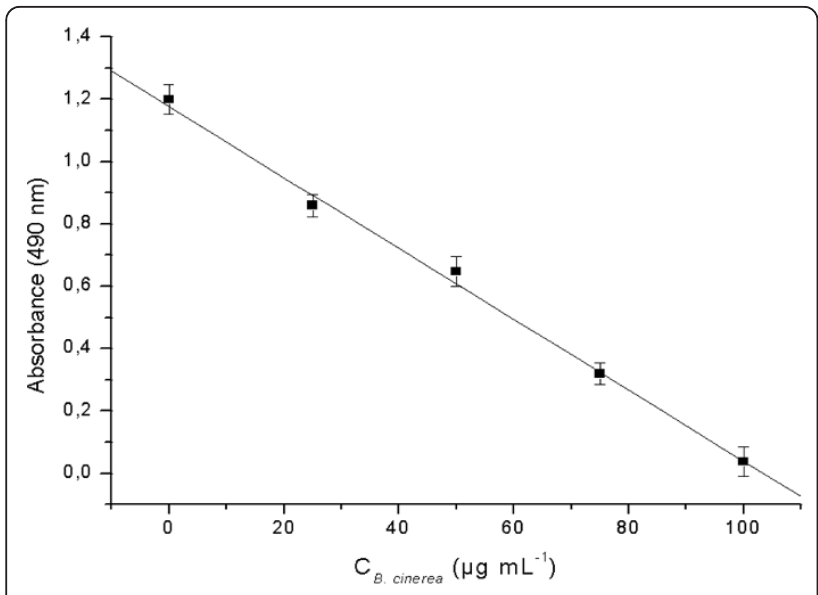

Figure 1 Standard curve for the indirect competitive ELISA made with purified antigens of $B$. cinerea covering a range of antigen concentration between 0 and $100 \mathrm{mg} \mathrm{mL}^{-1}$. Each value is based on five determinations. The error values represent the standard deviation

detected by the proposed method from infected fruit extracts samples obtained at 4,7 , and $10 \mathrm{~d}$ of incubation $\left(25^{\circ} \mathrm{C}\right)$, respectively, are presented in Table 2 . These results showed a correlation between the damage level and the amount of fungus present in the fruit samples. $B$. cinerea was detected even when the fruit rot was not visible yet but perhaps it had begun to germinate (about 4 days after inoculation and incubation of the fruit samples). Tests in which the fruit samples were infected using different conidia suspensions of $B$. cinerea were also made: $1 \times 10^{4}, 1 \times 10^{5}$, and $1 \times 10^{6}$ conidia $\mathrm{mL}^{-1}$, respectively. Absorbance measured after $4 \mathrm{~d}$ of incubation $\left(25^{\circ} \mathrm{C}\right)$ did not show significant differences (data not shown), because the method only detect germ tubes in the precise moment they appear, and the quantity of germinated conidia does not always depend of the quantity of inoculated conidia.

The accuracy was tested with dilution and recovery tests. A dilution test was performed with a control solution of $100 \mu \mathrm{g} \mathrm{mL}^{-1}$ B. cinerea purified antigens concentration in 0.01 M PBS, pH 7.2 (Figure 2).

Table 1 Within-assay precision (five measurements in the same run for each control) and between-assay precision (five measurements for each control, repeated for three consecutive days).

\begin{tabular}{ccccc}
\hline${ }^{\text {a }}$ Control solution & \multicolumn{2}{c}{ Within-assay } & \multicolumn{2}{c}{ Between-assay } \\
\cline { 2 - 5 } & Mean & CV \% & Mean & CV \% \\
\hline $5 \mu \mathrm{g} \mathrm{mL}^{-1}$ & 5.27 & 3.51 & 5.87 & 4.56 \\
$25 \mu \mathrm{g} \mathrm{mL}^{-1}$ & 24.56 & 2.87 & 25.30 & 5.80 \\
$75 \mu \mathrm{g} \mathrm{mL}^{-1}$ & 75.92 & 3.15 & 74.17 & 6.58 \\
\hline
\end{tabular}

${ }^{\mathrm{a}} \mu \mathrm{g} \mathrm{mL}{ }^{-1}$ B. cinerea antigen
Reproducibility assays were made using a repetitive standard $(\mathrm{n}=6)$ of $25 \mu \mathrm{g} \mathrm{mL} \mathrm{m}^{-1}$ B. cinerea (Table 3$)$.

The results obtained showed that the method developed had a lower Detection Limit and a shorter total assay time, than the non-competitive ELISA previously reported, and provided a wider dynamic range [28-32]. In addition, this method ELISA was developed for the quantification of $B$. cinerea in a complex matrix such as fruit tissues (apples, table grapes and pears samples).

\section{Cross-reactivity studies with fungi isolated from fruits}

The cross reactivity test of the monoclonal antibody for $B$. cinerea with the fungi frequently isolated from fruits (apples, table grapes and pears) resulted in no crossreactions, indicating that the antibody was specific to $B$. cinerea. The phytopathogens assayed were Penicillium expansum CEREMIC 151-2002, Aspergillus niger NRRL 1419, Aspergillus ochraceus NRRL 3174, Alternaria sp. NRRL 6410, Rhizopus sp. NRRL 695. In all cases absorbance read at $490 \mathrm{~nm}$ corresponded to maximum value indicating that the sample did not contain competitive antigens. We confirmed findings obtained by Meyer et al. [29], that BC-12.CA4 is highly selective to B. cinerea.

\section{Comparison of the proposed method with a DNA quantification method}

The method developed was compared with a DNA quantification method [33] for B. cinerea in 45 fruit samples (15 fruit samples of each kind: apple, table grape and pear). Concentrations of DNA were detected spectrophotometrically by measuring absorbance changes at $260 \mathrm{~nm}$ showed good integrity by the high molecular weight bands on electrophoresis (data not shown). The analysis was carried out with the extracts of fruits at 4,7 , and 10 $\mathrm{d}$ of incubation $\left(25^{\circ} \mathrm{C}\right)$, simultaneously with ELISA assay. The results obtained indicate a good correspondence between the two methods (Table 2). These results suggest that the sensitivity reached for this procedure allow determining very low level of $B$. cinerea antigens in apparently healthy fruit that can deteriorate suddenly due to the development of latent or quiescent infection into visible disease. Also, the DNA quantified by the method developed by González et al. [33] from uninfected and infected fruit extracts samples was amplified by PCR, with the purpose of verify if the same correspond to specific DNA of B. cinerea [34].

The Figure 3A shows the DNA-B. cinerea from infected fruit extracts samples (apples, table grapes and pears respectively). The bands observed in the lane 1 correspond to a standard of molecular weight marker (MW); in the lanes 2, 3 and 4 correspond to a molecular marker (IGS) for each fruit extracts; in the lanes 5, 6 and 7 correspond to the Boty transposable element for each fruit extract and in the lanes 8, 9 and 10 
Table 2 Correlation between the lesion diameters of the fruit samples, the amount of $B$. cinerea antigen determinated by the ELISA developed and the DNA of B. cinerea quantified from infected fruit extracts samples obtained at 4, 7, and 10 days of incubation $\left(25^{\circ} \mathrm{C}\right)$, respectively.

\begin{tabular}{|c|c|c|c|c|}
\hline Fruit samples & Days of incubation & ${ }^{\mathrm{b}}$ Lesion diameters ( $\mathrm{mm} / \mathrm{rot}$ ) & $\begin{array}{l}{ }^{c} B \text {. cinerea antigen } \\
\left(\mu \mathrm{gL}^{-1}\right)\end{array}$ & $\begin{array}{l}{ }^{\mathrm{C}} D N A-B \text {. cinerea } \\
\left(\mu \mathrm{g} \mathrm{mL}{ }^{-1}\right)\end{array}$ \\
\hline \multirow[t]{4}{*}{ Apples (Red-delicious) } & ${ }^{\text {a }}$ Control & uninfected & not detected & not detected \\
\hline & 4 & not visible & $10.53 \pm 0.48$ & $10.22 \pm 0.53$ \\
\hline & 7 & $20.11 \pm 0.54$ & $40.67 \pm 0.37$ & $38.75 \pm 0.41$ \\
\hline & 10 & $50.09 \pm 4.49$ & $69.08 \pm 0.43$ & $71.19 \pm 0.37$ \\
\hline \multirow[t]{4}{*}{ Table grapes (pink Moscatel) } & a Control & uninfected & not detected & not detected \\
\hline & 4 & not visible & $14.26 \pm 0.51$ & $13.86 \pm 0.54$ \\
\hline & 7 & $3.69 \pm 0.52$ & $49.03 \pm 0.46$ & $51.99 \pm 0.42$ \\
\hline & 10 & $5.35 \pm 0.14$ & $77.18 \pm 0.36$ & $75.84 \pm 0.41$ \\
\hline \multirow[t]{4}{*}{ Pears (William's) } & a Control & uninfected & not detected & not detected \\
\hline & 4 & not visible & $11.29 \pm 0.47$ & $12.76 \pm 0.51$ \\
\hline & 7 & $15.13 \pm 1.23$ & $41.78 \pm 0.55$ & $41.44 \pm 0.48$ \\
\hline & 10 & $38.98 \pm 1.67$ & $70.84 \pm 0.49$ & $72.39 \pm 0.52$ \\
\hline
\end{tabular}

${ }^{a}$ Negative control (uninfected fruits).

${ }^{b}$ Diameters of the lesion measured in the fruit samples at 4,7 and 10 days of incubation $\left(25^{\circ} \mathrm{C}\right)$ respectively.

b, c $X\left(\mu \mathrm{g} \mathrm{mL}{ }^{-1}\right)$, mean $\pm S D$, standard deviation.

correspond to the Flipper transposable element for each fruit extract. The Figure 3B shows control extracts made from uninfected fruits. There, only were observed bands in the lane 1 which correspond to a standard of molecular weight marker (MW) indicating clearly the absence of $B$. cinerea.

The presence of both transposable elements (Boty and Flipper) indicates that $B$. cinerea can be molecularly characterized as subpoblation transposa-type $[35,36]$.

\section{Conclusions}

In the present study, a specific and sensitive indirect competitive ELISA for the quantification of $B$. cinerea in

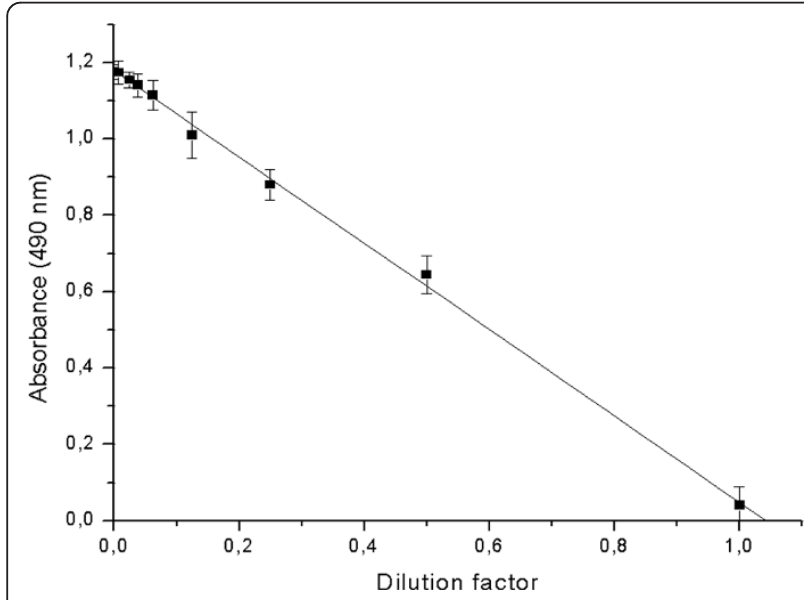

Figure 2 Dilution test using a control solution of $100 \mu \mathrm{g} \mathrm{mL}^{-1}$ B. cinerea purified antigen. Dilutions were made with $0.01 \mathrm{M} \mathrm{PBS}$, $\mathrm{pH}$ 7.2. Each value is based on five determinations. The error values represent the standard deviation. commercial apple, table grape and pear samples was developed and validated. This inexpensive and simplified method can be applied for 96 fruit samples, per each microtiter plate with a total time for the assay of 35 min. Preparations of immobilized antigen on surface microtiter plates were perfectly stable for at least 4 months assuring the reproducibility of the assay. This is one important advantage for the possible commercialization of the developed ELISA.

The results obtained suggest that the sensitivity reached for this procedure allows determining very low levels of $B$. cinerea antigens in apparently healthy fruits. Also, the validation procedures showed that the method developed was reliable and accurate and that was possible to correlate the quantities of $B$. cinerea antigens with DNA of $B$. cinerea present in fruit tissues. In addition, the immunological reaction between monoclonal antibodies for B. cinerea and antigens from others fungi,

Table 3 Reproducibility assays using repetitive standards $(\mathrm{n}=6)$ of $25 \mu \mathrm{g} \mathrm{mL}^{-1}$ B. cinerea antigen concentration.

\begin{tabular}{|c|c|}
\hline $\begin{array}{c}\text { Standards of } 25 \mu \mathrm{g} \mathrm{mL}^{-1} \text { B. cinerea } \\
\text { antigen }\end{array}$ & $\begin{array}{c}\text { Proposed method } \\
\left(\mu \mathrm{g} \mathrm{mL}^{-1}\right)\end{array}$ \\
\hline 1 & 25.60 \\
\hline 2 & 25.20 \\
\hline 3 & 24.16 \\
\hline 4 & 25.15 \\
\hline 5 & 24.98 \\
\hline 6 & 24.49 \\
\hline${ }^{a} \mathrm{X} \pm \mathrm{SD}$ & $24.93 \pm 0.52$ \\
\hline
\end{tabular}

${ }^{a} \mathrm{X}\left(\mu \mathrm{g} \mathrm{mL^{-1 } )}\right.$, mean $\pm \mathrm{SD}$, standard deviation. 
(A)

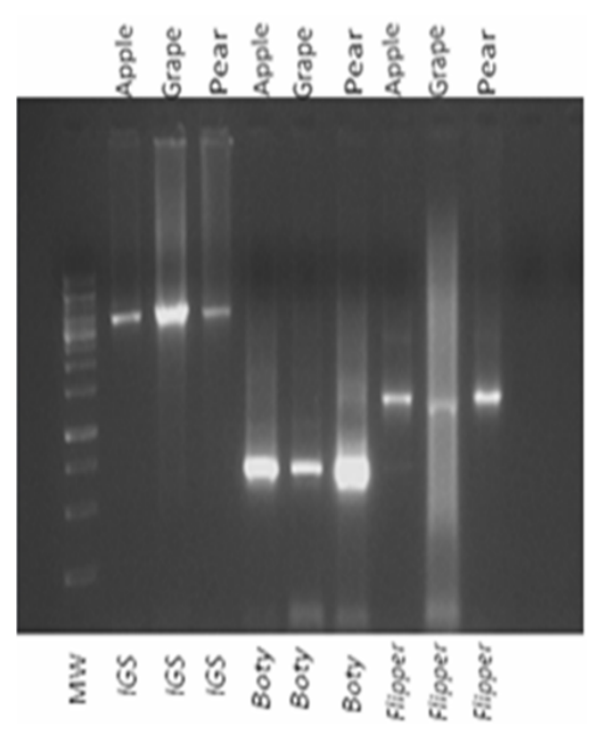

(B)

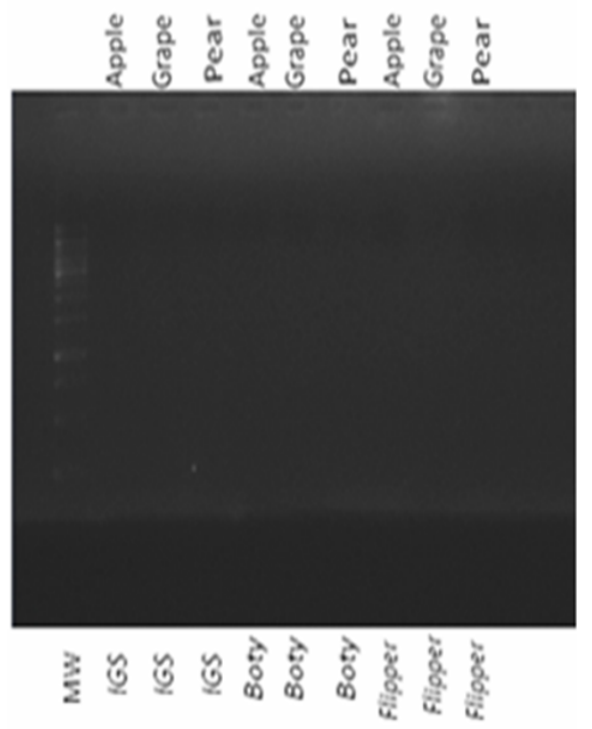

Figure 3 Gels show one sample of each kind of infected fruit extract with conidial suspensions $\left(1 \times 10^{5}\right.$ spores $\left.\mathrm{mL}^{-1}\right)$ and a control per each kind of uninfected fruit extract sample. (A) PCR product analysis of infected fruit extracts samples. Lane 1: standard molecular weight marker (MW). Lanes 2, 3 and 4: molecular marker IGS (ribosomal intergenic spacer). Lanes 5, 6 and 7: Boty transposable element. Lanes 8, 9 and 10: Flipper transposable element. (B) PCR product analysis of uninfected fruit extracts samples. Lane 1: standard molecular weight marker (MW). Lanes 2, 3, 4, 5, 6, 7, 8, 9 and 10: not observed any bands, indicating clearly the absence of $B$. cinerea.

frequently isolated from fruits resulted in no crossreactions.

In conclusion, this method promises to be particularly useful in the analysis of symptomless fruits, either to locate latent infections, avoiding thus, conventional culturing techniques, which are not only time-consuming, but also are not able to give a quantitative result.

\section{Methods}

\section{Reagents and Solutions}

All reagents used were of analytical reagent grade. The monoclonal antibody for B. cinerea (BC-12.CA4) and the secondary antibody-enzyme conjugate (anti-mouse polyvalent immunoglobulins peroxidase conjugate) were obtained from $A D G E N$ diagnostics (Auchincruive, Scotland) and Sigma Chemical (St. Louis, MO, USA) respectively. Glutaraldehyde (25\% aqueous solution), hydrogen peroxide $\left(\mathrm{H}_{2} \mathrm{O}_{2}\right)$, sodium clorure $(\mathrm{NaCl})$ and sulfuric acid $\left(\mathrm{H}_{2} \mathrm{SO}_{4}\right)$ were purchased from Merck (Darmstadt, Germany). Bovine serum albumin (BSA), Horseradish peroxidase (HRP), orthophenylenediamine (OPD) and Tween 20 were purchased from SigmaAldrich (St. Louis, MO, USA). All other reagents employed were of analytical grade and were used without further purification. Aqueous solutions were prepared using purified water from a Milli-Q-system. ELISA plate (Costar 3590, high binding polystyrene, 96 wells assay plate) was purchased from Costar (Corning, Massachusetts, USA).

\section{Intrumentation}

All solutions and reagents were conditioned to $37^{\circ} \mathrm{C}$ before the experiment, using a laboratory water bath Vicking Mason Ii (Vicking SRL, Argentina).

All $\mathrm{pH}$ measurements were made with an Orion Expandable Ion Analyzer (model EA 940, Orion Research, Cambridge, MA, USA) equipped with a glass combination electrode (Orion Research).

Absorbance was measured with an automatic ELISA reader (Bio-Rad 3550-UV Microplate Reader, Japan) and Beckman DU 520 General UV/vis spectrophotometer (USA).

All polymerase chain reactions (PCR) were carried out on the PCR Thermocycler (BIO-RAD, USA).

Microscopic studies were carried out on the Olympus CH 30 (Spectra services, N.Y., USA).

\section{PCR assays}

The primers used for PCR assays were: ribosomal region 18S (IGS spacer) 5'-ATGAGCCATTCGCAGTTTC-3' (GenBank Accession no: J01353). To determine the transposable elements status of each isolate, whether they were of vacuma or transposa type, we focused on the detection of Flipper with the primers F-300 
5'GCACAAAACCTACAGAAGA-3' (GenBank Accession no: U74294) and the detection of Boty with the two primers $B$-R 5'-TAACCTTGTCTTTGCTCATC-3 and $B$-L 5'-CCCAATTT-ATTCAATGTCAG-3'. (GenBank Accession no: X81790 and X81791).

Each reaction was performed with: $6 \mu \mathrm{L}$ of primers, $2.5 \mu \mathrm{L}$ of dNTP, $2.5 \mu \mathrm{L}$ of DNA, $2.5 \mu \mathrm{L}$ of $\mathrm{Mg}^{+2}$, and $0.5 \mu \mathrm{L}$ of Taq polymerase in a total volume of $50 \mu \mathrm{L}$.

PCR amplification conditions were: an initial denaturing step of $94^{\circ} \mathrm{C}$ by $4 \mathrm{~s} ; 35$ cycles of $94^{\circ} \mathrm{C}$ by $1 \mathrm{~s}, 60^{\circ} \mathrm{C}$ by $1 \mathrm{~s}$ and $72^{\circ} \mathrm{C}$ by $210 \mathrm{~s}$; and a final elongation step of $4 \mathrm{~s}$ at $72^{\circ} \mathrm{C}$ (Muñoz et al., 2008). The products were analyzed on agarose gel $2 \%$, stained with ethidium bromide and then observed under UV light (Figure 3).

\section{Preparation of the $\mathrm{B}$. cinerea antigens}

The purified $B$. cinerea antigens were prepared following the same procedure as a previous work [37].

B. cinerea Pers.: Fr (BNM 0527) was used in this study. The strain is deposited in the National Bank of Microorganisms (WDCM938) of the Facultad de Agronomia, Universidad de Buenos Aires (FAUBA). The isolates were maintained on potato dextrose agar (PDA) at $4^{\circ} \mathrm{C}$.

To induce the mycelial production, $B$. cinerea was grown on PDA for 8-12 days at $21 \pm 2^{\circ} \mathrm{C}$. After this incubation period, the mycelium was removed, frozen in liquid nitrogen, blended in a Waring ${ }^{\circledR}$ blender, and freeze-dried to obtain a fine powder. Then, the fine powder was suspended in $0.01 \mathrm{M}$ phosphate buffer (PBS, pH 7.2) and centrifuged at $1000 \times \mathrm{g}$ for $10 \mathrm{~min}$. The supernatant, which contained the antigen, was stored in $0.01 \mathrm{M} \mathrm{PBS}, \mathrm{pH} 7.2$, at $-20^{\circ} \mathrm{C}$ between uses. In this study, the concentration of antigen was expressed as Botrytis antigen units (B-AgU), which was equivalent to $\mu \mathrm{g} \mathrm{mL} \mathrm{m}^{-1}$ PBS extracts of freeze-dried fungal mycelium [29].

To induce the conidial production, $B$. cinerea was grown on PDA at $21 \pm 2^{\circ} \mathrm{C}$ until apparition of the mycelium, then the cultures were maintained at $15^{\circ} \mathrm{C}$ during a week. The conidia were harvested and suspended in $10 \mathrm{~mL}$ of sterile $0.01 \mathrm{M} \mathrm{PBS}$ (pH 7.2) containing $0.05 \%$ (v/v) Tween 80.

Finally, the concentration of spore suspension was determined with a Neubauer chamber and adjusted with in $0.01 \mathrm{M}$ PBS $(\mathrm{pH} 7.2)$ to $1 \times 10^{5}$ conidia $\mathrm{mL}^{-1}$. This conidia suspension was used to infect the fruit samples.

\section{Immobilization of purified antigen of B. cinerea on surface microtiter plates}

As the first step of the immobilization of purified antigen procedure, the microtiter plates were coated and incubated $4 \mathrm{~h}$ at room temperature in a moist chamber, with $100 \mu \mathrm{L}$ per well of an aqueous solution of $5 \%(w /$ w) glutaraldehyde at $\mathrm{pH} 10(0.20 \mathrm{M}$ sodium carbonate buffer) diluted 1:2 in 0.1 M PBS (pH 5). After washing twice with $0.1 \mathrm{M} \mathrm{PBS}(\mathrm{pH} 5), 100 \mu \mathrm{L}$ per well of antigens preparation $\left(10 \mu \mathrm{g} \mathrm{mL}^{-1} 0.01 \mathrm{M}\right.$ PBS, $\mathrm{pH}$ 7.2) were coupled to the residual aldehyde groups for $3 \mathrm{~h}$ at $37^{\circ} \mathrm{C}$. Later, two washes with $0.9 \% \mathrm{NaCl}$ and three washes with $0.01 \mathrm{M}$ PBS ( $\mathrm{pH} 7.2$ ) were carried out. After these wash steps, the surface of each well was blocked with $200 \mu \mathrm{L}$ of $1.5 \%$ BSA in $0.01 \mathrm{M}$ PBS (pH 7.2) for $1 \mathrm{~h}$ at $37^{\circ} \mathrm{C}$. The immobilized antigen was washed three times with PBST $\left(0.8 \% \quad \mathrm{NaCl}, \quad 0.11 \% \quad \mathrm{Na}_{2} \mathrm{HPO}_{4}, \quad 0.02 \%\right.$ $\mathrm{KH}_{2} \mathrm{PO}_{4}, 0.02 \% \mathrm{KCl}, 0.05 \%$ Tween $20, \mathrm{pH}$ 7.2).

Finally allowed to dry $5 \mathrm{~min}$ at room temperature and stored at $-20^{\circ} \mathrm{C}$ until use. Preparations of immobilized antigen were perfectly stable for at least 4 months.

\section{Indirect competitive ELISA for the B. cinerea quantification \\ Preparation of infected fruit extracts samples}

The preparation of infected fruit extracts samples was carried out according to the procedure described in our previous article [37].

In a first step, the fruit samples were infected using a spore suspension $\left(1 \times 10^{5}\right.$ conidia $\left.\mathrm{mL}^{-1}\right)$. Apples, pears, and table grapes were wounded using a punch. The wound size of apples and pears was $3 \mathrm{~mm} \times 3 \mathrm{~mm} \times 3$ $\mathrm{mm}$, whereas the one of table grapes was $1 \mathrm{~mm} \times 1$ $\mathrm{mm} \times 1 \mathrm{~mm}$. After that, $20 \mu \mathrm{L}$ of the conidia suspension was put into each wound. Then, the fruits were kept at $25^{\circ} \mathrm{C}$ and the evaluations of rot incidence and lesion diameters were made over 10 days. Ten fruits were used for each assay with three wounds each. Each experiment was repeated three times.

In a second step, fruit tissues infected and uninfected were removed and were ground to a fine powder in liquid $\mathrm{N}_{2}$.

Finally, the infected fruit extracts samples were prepared by adding $0.1 \mathrm{~g}$ of powdered fruit tissue into 0.9 $\mathrm{mL}$ of $0.01 \mathrm{M}$ PBS (pH 7.2) and vortexed for $1 \mathrm{~min}$ to obtain a homogeneous suspension, which was used in the immunological assay.

\section{Description of the immunological test}

Before starting the assay the microtiter plate with immobilized antigens was carried at room temperature for $5 \mathrm{~min}$. After, $25 \mu \mathrm{L}$ of fruit extracts samples and 25 $\mu \mathrm{L}$ of the monoclonal antibody IgG mouse anti- $B$. cinerea $\left(15 \mu \mathrm{g} \mathrm{mL}^{-1}\right.$ in $0.01 \mathrm{M}$ PBS, $\mathrm{pH}$ 7.2) were added to wells and incubated for $10 \mathrm{~min}$ at $37^{\circ} \mathrm{C}$. In this step, $B$. cinerea present in the fruit sample was allowed to compete by the specific monoclonal antibody with the immobilized purified $B$. cinerea antigens on surface of microtiter plates (Figure 4). After that, the plates were washed three times with PBST. Then, $50 \mu \mathrm{L}$ of the anti- 


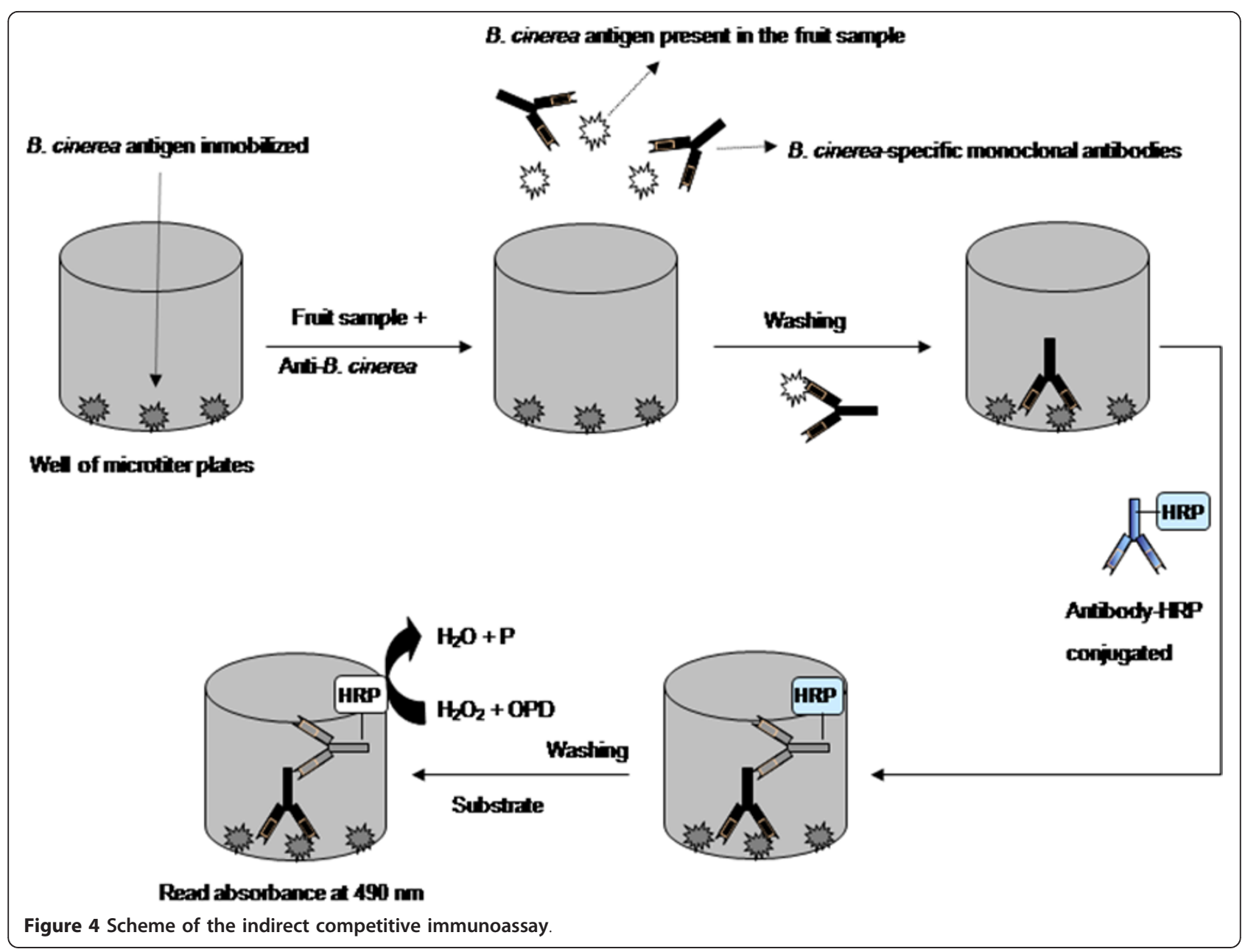

mouse IgG-HRP conjugate (diluted 0.75:1500 in 0.01 M PBS, pH 7.2) were added and incubated for $5 \mathrm{~min}$ at $37^{\circ}$ C. The plate was washed again three times with PBST and finally, $50 \mu \mathrm{L}$ of substrate solution (OPD $4 \mathrm{mg} / 5$ $\mathrm{mL}$; PCB $0.1 \mathrm{M}$ phosphate citrate, $10 \mu \mathrm{L} \mathrm{H}_{2} \mathrm{O}_{2}$ ) per well, were incorporated, and incubated for $3 \mathrm{~min}$ at room temperature. After $3 \mathrm{~min}$, the reaction was stopped with $50 \mu \mathrm{L}$ of $4 \mathrm{~N} \mathrm{H}_{2} \mathrm{SO}_{4}$. Absorbance values were determined using a microplate reader at $490 \mathrm{~nm}$.

The stock solution of substrate was prepared freshly before the experiment and stored in the darkness for the duration of the experiment.

Cross-reactivity studies with fungi isolated from fruits For the cross reaction study, the phytopathogenic fungi most common in Argentina were assayed. Penicillium expansum CEREMIC 151-2002, Aspergillus niger NRRL 1419, Aspergillus ochraceus NRRL 3174, Alternaria sp. NRRL 6410, Rhizopus sp. NRRL 695) were isolated from fruits (apples, table grapes and pears). Single spore cultures were incubated on PDA for 7 to 10 days at $21 \pm$ $2^{\circ} \mathrm{C}$. Water-soluble surface antigens were removed from plate cultures by flooding plates with $5 \mathrm{~mL}$ of $0.01 \mathrm{M}$ PBS, pH 7.2. Solutions obtained previously were transferred to $1.5-\mathrm{mL}$ eppendorf tubes and centrifuged to remove particulate materials. The supernatant was diluted 1:5 with $0.01 \mathrm{M}$ PBS, $\mathrm{pH} 7.2$ and used as described our method above, except that the $25 \mu \mathrm{L}$ of fruit extracts were replaced for $25 \mu$ l of the diluted supernatant (phytopathogenic fungi isolated from fruits). Finally, the absorbance was measured by ELISA microplate reader at $490 \mathrm{~nm}$.

\section{Acknowledgements}

The authors wish to thank the financial support from the Universidad Nacional de San Luis, the Agencia Nacional de Promoción Científica y Tecnológica, and the Consejo Nacional de Investigaciones Científicas y Técnicas (CONICET).

\section{Authors' contributions}

MFB participated in the design of the study, performed experiments and drafted the manuscript. JF carried out the molecular genetic studies. SP and GM contributed to coordinate the study. ES helped in microbiological assays and in the obtention of antigen. JR helped to draft the manuscript and 
critically revised the manuscript. MSF participated in the study conception and coordination, provided guidance during all parts of the work, and helped to draft the manuscript. All authors read and approved the final version of the manuscript.

Received: 13 June 2011 Accepted: 4 October 2011

Published: 4 October 2011

\section{References}

1. Dewey F, Hill M, DeScenzo R: Quantification of Botrytis and laccase in wine grapes. Am J Enol Vitic 2008, 59:47-54.

2. Dewey F, Meyer U: Rapid quantitative tube immunoassays for on-site detection of Botrytis, Aspergillus and Penicillium antigens in grape juice. Anal Chim Acta 2004, 513:11-19.

3. Muñoz C, Gómez Talquenca S, Volpe M: Tetra primer ARMS-PCR for identification of SNP in $\beta$-tubulin of Botrytis cinerea, responsible of resistance to benzimidazole. J Microbiol Meth 2009, 78:245-246.

4. Mosbach A, Leroch M, Mendgen KW, Hahn M: Lack of evidence for a role of hydrophobins in conferring surface hydrophobicity to conidia and hyphae of Botrytis cinerea. BMC Microbiology 2011, 11:10-21.

5. De Kock S, Holz G: Blossom-end rot of pears: systemic infection of flowers and immature fruit by Botrytis cinerea. J Phytopathol 1992, 135:317-327.

6. Jarvis W: Latent infections in the pre- and postharvest environment. Hort Science 1994, 29:749-751.

7. Lavy-Mair G, Barkai-Golan R, Kopeliovitch E: Initiation at the stage of postharvest Botrytis stem-end rot in normal and non-ripening fruits. Ann Appl Biol 1988, 112:393-396.

8. McNicol R, Williamson B: Systemic infection of black currant flowers by Botritis cinerea and its possible involvement in premature abscission of fruits. Ann Appl Biol 1989, 114:243-254.

9. Morales-Valle H, Silva L, Paterson R, Oliveira J, Venâncio A, Lima N: Microextraction and Gas Chromatography/Mass Spectrometry for improved analysis of geosmin and other fungal "off" volatiles in grape juice. J Microbiol Meth 2010, 83:48-52.

10. Thompson J, Latorre B: Characterization of Botrytis cinerea from table grapes in Chile using RAPD-PCR. Plant Dis 1999, 83:1090-1094.

11. Eckert J, Ogawa J: The chemical control of postharvest diseases: subtropical and tropical fruits. Annu Rev Phytopathol 1988, 23:421-454.

12. Spotts R, Cervantes L: Population, pathogenicity, and benomyl resistance of Botrytis spp., Penicillium spp., and Mucor piriformis in packinghouses. Plant Dis 1986, 70:106-108.

13. Ragsdale $\mathrm{N}$ : The impact of the food quality protection act on the future of plant disease management. Annu Rev Phytopathol 2000, 38:577-596.

14. Sansone G, Calvente V, Rezza I, Benuzzi D, Sanz M: Biological control of Botrytis cinerea strains resistant to Iprodione. Postharvest Biology and Technology 2005, 35:229-339.

15. Dewey F, Yohalem D: Detection, quantification and immunolocalisation of Botrytis species. In Botrytis: Biology, Pathology and Control. Volume Chapter 11. Edited by: Elad Y, et al. London; 2007:181-194.

16. Eriksson $R$, Jobs M, Ekstrand C, Ullberg M, Herrmann B, Landegren U, Nilsson M, Blomberg J: Multiplex and quantifiable detection of nucleic acid from pathogenic fungi using padlock probes, generic real time PCR and specific suspension array readout. J Microbiol Meth 2009, 78:195-202.

17. Gao X, Jackson K, Lambert S, Hartman G, Niblack T: Detection and quantification of Fusarium solani in soybean roots with real-time quantitative polymerase chain reaction. Plant Dis 2004, 88:1372-1380.

18. Leisova L, Minarikova V, Kucera L, Ovesna J: Quantification of Pyrenophora teres in infected barley leaves using real-time PCR. J Microbiol Meth 2006, 67:446-455.

19. Lopez M, Bertolini E, Olmos A, Caruso P, Gorris M, Llop P, Penyalver R, Cambra M: Innovative tools for detection of plant pathogenic viruses and bacteria. Int Microbiol 2003, 6:233-243.

20. McCartney $H$, Foster S, Fraaije B, Ward E: Molecular diagnostics for fungal plant pathogens. Pest Manag Sci 2003, 59:129-142.

21. Savazzini F, Oliveira Longa C, Pertot I, Gessler C: Real-time PCR for detection and quantification of the biocontrol agent Trichoderma atroviride strain SC1 in soil. J Microbiol Meth 2008, 73:185-194.

22. Schaad N, Frederick R: Real-time PCR and its application for rapid plant disease diagnostics. Can J Plant Pathol 2002, 24:250-258.
23. Ward E, Foster S, Fraaije B, McCartney H: Plant pathogen diagnostics: immunological and nucleic acid-based approaches. Ann Appli Biol 2004, 145:1-16.

24. Xie Z, Thompson A, Kashleva H, Dongari-Bagtzoglou A: A quantitative realtime RT-PCR assay for mature $C$. albicans biofilms. BMC Microbiology 2011, 11:93-100.

25. Serrano R, Gusmão L, Amorim A, Araujo R: Rapid identification of Aspergillus fumigatus within the section Fumigati. BMC Microbiology 2011, 11:82-88.

26. He F, Soejoedono RD, Murtini S, Goutama M, Kwang J: Complementary monoclonal antibody-based dot ELISA for universal detection of $\mathrm{H} 5$ avian influenza virus. BMC Microbiology 2010, 10:330-338

27. Rigano LA, Marano MR, Castagnaro AP, Do Amaral AM, Vojnov AA: Rapid and sensitive detection of Citrus Bacterial Canker by loop-mediated isothermal amplification combined with simple visual evaluation methods. BMC Microbiology 2010, 10:176-183.

28. Dewey F, Ebeler S, Adams D, Noble A, Meyer U: Quantification of Botrytis in grape juice determined by a monoclonal antibody-based immunoassay. Am J Enol Vitic 2000, 51:276-282.

29. Meyer U, Spotts R, Dewey F: Detection and quantification of Botrytis cinerea by ELISA in pear stems during cold storage. Plant Dis 2000, 84:1099-1103.

30. Obanor F, Walter M, Waipara N, Cernusko R: Rapid method for the detection and quantification of Botrytis cinerea in plant tissues. New Zealand Plant Protection 2002, 55:150-153.

31. Obanor F, Williamson K, Mundy D, Wood P, Walter M: Optimisation of PTAELISA detection and quantification of Botrytis cinerea infections in grapes. New Zealand Plant Protection 2004, 57:130-137.

32. Ricker R, Marois J, Dlott R, Morrison J: Immunodetection and quantification of Botrytis cinerea on harvested wine grapes. Phytopathology 1991, 81:404-411.

33. González C, Noda J, Espino J, Brito N: Drill-assisted genomic DNA extraction from Botrytis cinerea. Biotechnol Lett 2008, 30:1989-1992.

34. Muñoz C, Gómez Talquenca S, Oriolani E, Arias F: Identificación rápida de distintas razas de Botrytis cinerea en cultivos de vid. Enologia 2008, 6:5-7.

35. Giraud T, Dominique F, Levis $C$, Leroux P, Brygoo Y: RFLP Markers show genetic recombination in Botrytinia Fuckeliana (Botrytis cinerea) and transposable element reveal two sympatric species. Mol Biol Evol 1997, 11:1177-1185.

36. Giraud T, Fortini D, Levis C, Lamarque C, Leroux P, Lo Buglio K, Brygoo Y: Two sibling species of the Botrytis cinerea complex, transposa and vacuma, are found in sympatry on numerous host plants. Phytopathology 1999, 89:967-973.

37. Fernández-Baldo M, Messina GA, Sanz MI, Raba J: Microfluidic immunosensor with micro magnetic beads coupled to Carbon-based Screen-Printed Electrodes (SPCEs) for determination of Botrytis cinerea in tissue of fruits. J Agric Food Chem 2010, 58:11201-11206.

doi:10.1186/1471-2180-11-220

Cite this article as: Fernández-Baldo et al:: Development of an indirect competitive enzyme-linked immunosorbent assay applied to the Botrytis cinerea quantification in tissues of postharvest fruits. BMC Microbiology 2011 11:220.

\section{Submit your next manuscript to BioMed Central and take full advantage of:}

- Convenient online submission

- Thorough peer review

- No space constraints or color figure charges

- Immediate publication on acceptance

- Inclusion in PubMed, CAS, Scopus and Google Scholar

- Research which is freely available for redistribution 